\title{
Integrated Management of Wilt Disease in Chickpea
}

\author{
M.K. Chudasama* and M.S. Pithia \\ Pulses Research Station, Junagadh Agricultural University, Junagadh- 362001, India \\ *Corresponding author
}

\section{A B S T R A C T}

\begin{tabular}{|c|}
\hline Keywords \\
\hline $\begin{array}{l}\text { Trichoderma } \\
\text { harzianum, Fusarium } \\
\text { oxysporum f. sp. } \\
\text { ciceri, Carboxin, Cicer } \\
\text { arietinum }\end{array}$ \\
\hline Article Info \\
\hline $\begin{array}{l}\text { Accepted: } \\
10 \text { January } 2018 \\
\text { Available Online: } \\
10 \text { February } 2018\end{array}$ \\
\hline
\end{tabular}

\section{Introduction}

Gram or chickpea (Cicer arietinum L.) is one of the most important Rabi pulse crops. Chickpea attacked by numerous root pathogens, of which the most destructive is Fusarium oxysporum f. sp. ciceri causing vascular wilt. India is a major chickpea growing country producing around $75 \%$ of the world's supply (Tomar et al., 2010).

Chickpea wilt is soil and seed-borne; facultative saprophyte and survive in soil for two to three years (Haware et al., 1978). Wilt is the common and frequently occurring diseases of chickpea and causes considerable yield loss (Haware et al., 1996; Kaur and
Wilt disease of chickpea caused by Fusarium oxysporum f. sp. ciceri is serious biotic arm. To find out the effective management of the diseases through chemicals and soil application of biocontrol agents, the field studies were conducted during Rabi season of 2012-13, 2013-14 and 2014-15. Seed treatment checked the incidence of wilt and increased the yield of chickpea. However, combined applications of seed treatment with ichoderma sp. as well as soil application significantly checked the disease incidence (3.80) and increased the grain yield $(1352 \mathrm{~kg} / \mathrm{ha})$. The pooled result of three years wilt incidence of 3.78 per cent recorded in carboxin + Thiram @2 goil application of $T$. harzianum @ $4 \mathrm{~kg} / \mathrm{ha}\left(\mathrm{T}_{7}\right)$ at the time of sowing and maximum grain yield $1352 \mathrm{~kg} / \mathrm{ha}$ was recorded in T. harzianum @ $4 \mathrm{~g} / \mathrm{ha}$ of seed as a seed treatment + soil application of T.harzianum @ $4 \mathrm{~kg} / \mathrm{ha}\left(\mathrm{T}_{6}\right)$ at the time of sowing.

Mukhopadhyay, 1992). Fusarium oxysporum f. sp. ciceri (Padwick) Synd. and Hans. is considered to be the primary cause of wilt disease in chickpea (Chattopadhyay and Sen Gupta, 1967). These cause complete losses in grain yield, if the diseases occur in the vegetative and reproductive stages of the crop (Haware and Nene, 1980). Researchers have shown that commonly grown cultivars of chickpea in India may suffer from $9-41 \%$ seed yield loss due to wilt, depending on the cultivar and disease severity (Khan et al., 2004). Biological control is one of the best low-cost and ecologically sustainable methods for managing plant diseases caused by soilborne pathogens like Fusarium, Macrophomina, Rhizoctonia, etc. Research 
shows that seed and soil applications of different strains of $T$. harzianum successfully control wilt disease caused by $F$. oxysporum $\mathrm{f}$. sp. ciceri under pot conditions (Rudresh et al., 2005; Kumar et al., 2008) and field conditions (Prasad et al., 2002; Dubey et al., 2012). The present study was undertaken to examine the performance of Trichoderma harzianum through seed treatment and soil application. The fungicidal seed treatment will not severe the complete control of the disease, hence experiment was conducted to manage the disease through bio agent, too.

\section{Materials and Methods}

The study was conducted at Pulses Research station, Junagadh Agricultural University, Junagadh during three consecutive years in the Rabi: 2012-13, 2013-14 and 2014-15 in Randomized Block Design with ten treatments along with four replications using cultivar Gujarat Junagadh Gram-3. The crop was sown with $45 \times 10 \mathrm{~cm}$ spacing having a gross plot size of $3.0 \times 2.70 \mathrm{~m}$ and net plot size of $4.8 \times$ $2.4 \mathrm{~m}$. The seed rate was used at $60 \mathrm{~kg} / \mathrm{ha}$. The experiment was performed in fusarium wilt infected sick soil. The bioagent used in the present investigations was $T$. harzianum and different fungicides viz. vitavex powder, carbendazim and thiram. Per cent disease incidence in each treatment was calculated using the following formula.

$$
\text { Wilt incidence }(\%)=\frac{\text { No. of Plant wilted }}{\text { Total Plant stand }}
$$

The benefit cost ratio was calculated on the basis of prevailing market prices of chickpea and other inputs. Benefit cost ratio was calculated as follows:

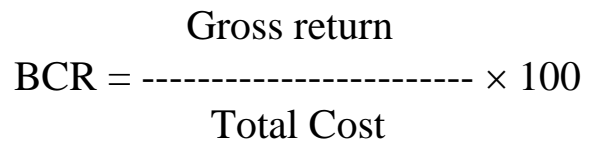

The field experiments comprised of 7 treatments and control (untreated check) given as below

\section{Results and Discussion}

Three years pooled analysis for management of chickpea wilt presented in Table 1. It revealed that all the treatments were found significantly effective over the control. Minimum wilt incidence of 3.78 per cent was recorded in carboxin + Thiram (Vitavax power)@2 g/kg seed + soil application of $T$. harzianum @ $4 \mathrm{~kg} / \mathrm{ha}\left(\mathrm{T}_{7}\right)$ at the time of sowing, but it was at par with $\mathrm{T}_{6}, \mathrm{~T}_{1}$ and $\mathrm{T}_{4}$ $(3.80 \%, 4.36 \%$ and $4.41 \%$, respectively). The maximum wilt incidence 8.74 per cent was recorded in control.

Results of grain yield showed in Table 2 indicated that maximum grain yield 1352 $\mathrm{kg} / \mathrm{ha}$ was recorded in T. harzianum @ $4 \mathrm{~g} / \mathrm{ha}$ of seed as a seed treatment + soil application of $T$. harzianum @ $4 \mathrm{~kg} / \mathrm{ha}\left(\mathrm{T}_{6}\right)$ at the time of sowing, but it was at par with $\mathrm{T}_{7}$ and $\mathrm{T}_{4}$ (1309 $\mathrm{kg} / \mathrm{ha}$ and $1261 \mathrm{~kg} / \mathrm{ha}$ ). The minimum grain yield $(927 \mathrm{~kg} / \mathrm{ha})$ was recorded in control. While considering the cost of treatments, maximum net return of Rs. 16253/ ha was recorded in the treatment of T. harzianum @ 4 $\mathrm{g} / \mathrm{kg}$ of seed as a seed treatment + soil application of $T$. harzianum @ $4 \mathrm{~kg} / \mathrm{ha}$ at the time of sowing $\left(\mathrm{T}_{6}\right)$ followed by Rs. Rs. $14300 /$ ha in treatment of carboxin + Thiram @ $2 \mathrm{~g} / \mathrm{kg}$ seed + soil application of $T$. harzinanum @ $4 \mathrm{~kg} / \mathrm{ha}\left(\mathrm{T}_{7}\right)$ at the time of sowing.

The differences in the wilt incidence and grain yield between treatments $\mathrm{T}_{7}$ and $\mathrm{T}_{6}$ were nonsignificant there was a large difference in net return and ICBR.

Therefore the best treatment was $\mathrm{T}_{6}\left(\mathrm{~T}_{1}+\right.$ Soil application of $T$. harzanium @ $4 \mathrm{~kg} / \mathrm{ha}$ at the time of sowing. 
Table.1 Details of treatments

\begin{tabular}{|c|c|}
\hline Sr. No. & Name of Treatment \\
\hline $\mathbf{T}_{1}$ & Trichoderma harzianum (Pusa 5 SD) @ 4g / kg of seed \\
\hline $\mathbf{T}_{2}$ & Carboxin + Thiram (Vitavax power)@ $2 \mathrm{~g} / \mathrm{kg}$ seed \\
\hline $\mathbf{T}_{3}$ & Trichoderma harzianum (Pusa 5 SD) @ 4g + Carboxin + Thiram (Vitavax power) @ 1g a.i. / kg seed \\
\hline $\mathbf{T}_{4}$ & Carboxin@ @g / kg seed \\
\hline $\mathbf{T}_{5}$ & Carbendazim + Thiram (1:2 ratio) @ 3g / kg seed \\
\hline $\mathbf{T}_{6}$ & $\mathrm{~T}_{1}+$ Soil application of $T$. harzianum @ $4 \mathrm{~kg} / \mathrm{ha}$ at the time of Sowing. \\
\hline $\mathbf{T}_{7}$ & $\mathrm{~T}_{2}+$ Soil application of $T$. harzianum @ $4 \mathrm{~kg} / \mathrm{ha}$ at the time of Sowing. \\
\hline $\mathbf{T}_{8}$ & Control \\
\hline
\end{tabular}

Table.2 Effect of different treatments on wilt incidence in chickpea

\begin{tabular}{|c|c|c|c|c|c|}
\hline \multirow{2}{*}{$\begin{array}{l}\text { Sr. } \\
\text { No. }\end{array}$} & \multirow[t]{2}{*}{ Treatment } & \multicolumn{3}{|c|}{ Disease Incidence (\%) } & \multirow[t]{2}{*}{ Pooled } \\
\hline & & $(2012-13)$ & $(2013-14)$ & $(2014-15)$ & \\
\hline T1 & $\begin{array}{l}\text { Trichoderma harzianum (Pusa 5 SD) @ 4g / kg of } \\
\text { seed }\end{array}$ & $2.19(4.82)$ & $2.20(4.85)$ & $1.86(3.48)$ & $2.10(4.36)$ \\
\hline $\mathbf{T 2}$ & Carboxin + Thiram (Vitavax power) @ 2g / kg seed & $2.17(4.70)$ & $2.15(4.61)$ & $2.09(4.39)$ & $2.14(4.57)$ \\
\hline T3 & $\begin{array}{l}\text { Trichoderma harzianum (Pusa 5 SD) @ 4g + } \\
\text { Carboxin + Thiram (Vitavax power) @ 1g a.i. / kg } \\
\text { seed }\end{array}$ & $2.02(4.09)$ & $2.04(4.17)$ & $1.87(3.52)$ & $1.98(3.92)$ \\
\hline T4 & Carboxin@2g/kg seed & $2.05(4.22)$ & $2.37(5.61)$ & $1.88(3.53)$ & $2.10(4.41)$ \\
\hline T5 & Carbendazim + Thiram (1:2 ratio) @ 3g / kg seed & $2.06(4.26)$ & $2.30(5.28)$ & $1.94(3.76)$ & $2.10(4.41)$ \\
\hline T6 & $\begin{array}{l}\mathrm{T} 1+\text { Soil application of } T . \text { harzianum @ } 4 \mathrm{~kg} / \mathrm{ha} \text { at the } \\
\text { time of Sowing. }\end{array}$ & $2.12(4.51)$ & $2.10(4.41)$ & $1.63(2.65)$ & $1.95(3.80)$ \\
\hline $\mathbf{T} 7$ & $\begin{array}{l}\mathrm{T} 2+\text { Soil application of } T \text {. harzianum @ 4kg/ha at } \\
\text { the time of Sowing. }\end{array}$ & $2.04(4.15)$ & $\mathbf{2 . 0 3}(4.12)$ & $\begin{array}{c}1.76 \\
(3.11)\end{array}$ & $1.94(3.78)$ \\
\hline \multirow[t]{5}{*}{ T8 } & Control & $3.10(9.63)$ & $2.96(8.89)$ & $2.80(7.85)$ & $2.96(8.74)$ \\
\hline & S.Em. \pm & 0.082 & 0.1103 & 0.0826 & 0.053 \\
\hline & C.D. at $5 \%$ & 0.2412 & 0.3245 & 0.243 & 0.151 \\
\hline & C.V. \% & 7.38 & 9.73 & 8.29 & 8.57 \\
\hline & $\mathbf{Y} \times \mathbf{T}$ & NS & & & \\
\hline
\end{tabular}

Note: $\sqrt{\mathrm{x}}$ transform value Data in parenthesis are retransformed values.

Table.3 Effect of different treatments on grain yield in chickpea

\begin{tabular}{|c|c|c|c|c|c|}
\hline \multirow{2}{*}{$\begin{array}{l}\text { Sr. } \\
\text { No. }\end{array}$} & \multirow[t]{2}{*}{ Treatment } & \multicolumn{3}{|c|}{ Disease Incidence (\%) } & \multirow[t]{2}{*}{ Pooled } \\
\hline & & $(2012-13)$ & $(2013-14)$ & $(2014-15)$ & \\
\hline T1 & $\begin{array}{l}\text { Trichoderma harzianum (Pusa 5 SD) @ 4g / kg of } \\
\text { seed }\end{array}$ & 1127 & 1187 & 1059 & 1124 \\
\hline $\mathbf{T 2}$ & Carboxin + Thiram (Vitavax power) @ 2g / kg seed & 1118 & 1133 & 1244 & 1165 \\
\hline T3 & $\begin{array}{l}\text { Trichoderma harzianum (Pusa } 5 \text { SD) @ } 9 \mathrm{~g}+ \\
\text { Carboxin + Thiram (Vitavax power) @ } 1 \mathrm{~g} \text { a.i. / kg } \\
\text { seed }\end{array}$ & 1280 & 1211 & 1250 & 1247 \\
\hline T4 & Carboxin@2g/kg seed & 1248 & 1306 & 1231 & 1261 \\
\hline T5 & Carbendazim + Thiram (1:2 ratio) @ 3g / kg seed & 1110 & 1204 & 1286 & 1200 \\
\hline T6 & $\begin{array}{l}\mathrm{T} 1+\text { Soil application of } T \text {. harzianum @ } 4 \mathrm{~kg} / \mathrm{ha} \text { at the } \\
\text { time of Sowing. }\end{array}$ & 1242 & 1340 & 1476 & 1352 \\
\hline T7 & $\begin{array}{l}\mathrm{T} 2+\text { Soil application of } T \text {. harzianum @ 4kg/ha at } \\
\text { the time of Sowing. }\end{array}$ & 1217 & 1336 & 1372 & 1309 \\
\hline \multirow[t]{5}{*}{ T8 } & Control & 883 & 904 & 995 & 927 \\
\hline & S.Em. \pm & 44.3 & 62.099 & 50.74 & 30.55 \\
\hline & C.D. at $5 \%$ & 130.4 & 182.716 & 149.25 & 86.36 \\
\hline & C.V. \% & 7.7 & 10.33 & 8.2 & 8.83 \\
\hline & $\mathbf{Y} \times \mathbf{T}$ & N.S. & & & \\
\hline
\end{tabular}


Table.4 Economics of different treatments for the control of wilt of chickpea

\begin{tabular}{|c|c|c|c|c|c|c|c|c|}
\hline \multirow[t]{2}{*}{$\begin{array}{l}\text { Sr. } \\
\text { No. }\end{array}$} & \multirow[t]{2}{*}{ Treatment } & \multirow{2}{*}{$\begin{array}{c}\text { Yield } \\
\text { Increased } \\
\text { over control }\end{array}$} & \multirow{2}{*}{$\begin{array}{l}\text { Gross } \\
\text { Income } \\
\text { (RS.) }\end{array}$} & \multicolumn{2}{|c|}{$\begin{array}{l}\text { Expenditure Cost } \\
\text { (Rs.) }\end{array}$} & \multirow{2}{*}{$\begin{array}{l}\text { Total } \\
\text { Expenditure } \\
\quad \text { (Rs.) }\end{array}$} & \multirow{2}{*}{$\begin{array}{l}\text { Net } \\
\text { Return } \\
\text { (Rs.) }\end{array}$} & \multirow[t]{2}{*}{ ICBR } \\
\hline & & & & $\begin{array}{c}\text { Material } \\
\text { cost/ha }\end{array}$ & Labour & & & \\
\hline T1 & $\begin{array}{l}\text { Trichoderma harzianum (Pusa 5 SD) @4g / kg of } \\
\text { seed }\end{array}$ & 197 & 7880 & 17 & - & 17 & 7863 & $1: 462.53$ \\
\hline $\mathbf{T 2}$ & Carboxin + Thiram (Vitavax power)@ 2g / kg seed & 238 & 9520 & 250 & - & 250 & 9270 & $1: 37.08$ \\
\hline T3 & $\begin{array}{l}\text { Trichoderma harzianum (Pusa 5 SD) @ 4g + } \\
\text { Carboxin + Thiram (Vitavax power) @ 1g a.i. / kg } \\
\text { seed }\end{array}$ & 320 & 12800 & 267 & - & 267 & 12533 & $1: 46.94$ \\
\hline T4 & Carboxin@2g/kg seed & 334 & 13360 & 264 & & 264 & 13096 & $1: 49.60$ \\
\hline T5 & Carbendazim + Thiram (1:2 ratio) @ 3g / kg seed & 273 & 10920 & 106 & & 106 & 10814 & $1: 102.02$ \\
\hline T6 & $\begin{array}{l}\mathrm{T} 1+\text { Soil application of T. harzianum @ } 4 \mathrm{~kg} / \mathrm{ha} \text { at } \\
\text { the time of Sowing. }\end{array}$ & 425 & 17000 & 297 & 450 & 747 & 16253 & $1: 21.76$ \\
\hline T7 & $\begin{array}{l}\mathrm{T} 2+\text { Soil application of } T \text {. harzianum @ } 4 \mathrm{~kg} / \mathrm{ha} \text { at } \\
\text { the time of Sowing. }\end{array}$ & 382 & 15820 & 530 & 450 & 980 & 14300 & $1: 14.59$ \\
\hline
\end{tabular}

Price of one kilogram (Rs): Chickpea seed-40/-, Carbendazim-960/-, Thiram-400/-, Carboxin -2200/-, Trichoderma harzianum -70/-, Carboxin + Thiram -2080Labourer cost: 150 Rs/day 
Manjunatha et al., (2013) reported minimum root rot incidence of chickpea $(2.67 \%)$ with higher seed germination $(97.60 \%)$ and seed yield (1274 kg/ha) achieved through seed treatment of $T$. viride + soil application of FYM at 4 kg/plot. Rudresh et al., (2005) reported significant control of wet root rot and Fusarium wilt of chickpea by soil application of $T$. harzianum (PDBCTH) and T. virens (PDBCTV12), respectively. Soil application of $T$. harzianum, $T$. viride, and $T$. virens has been found to be effective in controlling root rot (Khan and Gupta, 1998; Ganesan et al., 2007; Kumar et al., 2008) and wilt diseases (Prasad et al., 2002; Dubey et al., 2012). In the present study, seed treatment and soil application of $T$. harzianum provided better disease control with greater crop yield enhancement. Pandey et al., (2017) reported singnificantly loweset wilt incidance and root rot $(8.59 \%)$ and highest seed germination (96.69 \%), vigour index (2734) and grain yield $(1535 \mathrm{~kg} / \mathrm{ha})$ in the treatment $\mathrm{T} 5$ i.e. seed biopriming for $10 \mathrm{hrs}$ with suspension of talc based formulation $\left(2 \times 10^{8} \mathrm{cfu} / \mathrm{g}\right)$ of $T$. viride @ $50 \mathrm{~g}$ in $250 \mathrm{ml}$ of water/ kg of seed + soil application of $T$. viride enriched FYM (10 $\mathrm{kg}$ bioagent/ ton FYM) in furrow @ 1 ton/ ha Animisha et al., (2012).

Lowest percentage of wilt $(19.0 \%)$ was found with $T$. viride $\left(\mathrm{T}_{2}\right)$ followed by carbendazim $(21 \%)$, neem cake $(42.6 \%)$, carbendazim + neem cake $(45.2 \%)$, carbendazim $+T$. viridae $(47.2 \%)$, neem cake $+T$. viridae $(48.2 \%)$. Sharma et al., (2005) reported that the combination of neem cake + carbendazim + T. harzianum provided the highest control of the disease Fusarium yellows caused by Fusarium oxysporum f. sp. gladioli. Nikam et al., (2007) reported that combined soil application of $T$. viride and ground nut cake followed by neem cake had given good control against chickpea wilt caused by Fusarium oxysporum f. sp. cicero (Table 3 and 4).
Looking to the effectiveness of different treatments grain yield and economics, the best treatment was seed treatment of $T$. harzanium (Pusa 5 SD) @ $4 \mathrm{~g} / \mathrm{Kg}$ seed along with soil application of $T$. harzianum @ $4 \mathrm{~kg} / \mathrm{ha}$ at the time of sowing.

\section{References}

Animisha et al., (2012). Integrated management of Chickpea wilt incited by Fusarium oxysporium f. sp. ciceri. Int. J. of Agri. Res. 7(5): 284-290.

Chattopadhyay, S.B. and Sen Gupta, P.K. 1967. Studies on wilt diseases of pulses I. Variation and taxonomy of Fusarium spp. associated with the wilt disease of pulses. Indian J. Mycol. Res., 5: 45-53.

Dubey, S.C., Tripathi, A. and Singh, B. 2012. Combination of soil application and seed treatment formulations of Trichoderma species for integrated management of wet root rot caused by Rhizoctonia solani in chickpea (Cicer arietinum). Indian J. Agri. Sci., 82: 356-362.

Ganesan, S., Kuppusamy, R.G. and Sekar, R. 2007. Integrated management of stem rot disease (Sclerotium rolfsii) of groundnut (Arachis hypogaea L.) using rhizobium and Trichoderma harzianum (ITCC - 4572). Turkish J. Agri. Forestry, 31: 103-108.

Haware, M. P., Nene, Y. L. and Natarajan, M. 1996. The survival of Fusarium oxysporum f. sp. ciceri in soil in the absence of chickpea. Phytopathologia Mediterranea, 35: 12-19.

Haware, M. P., Nene, Y. L. and Rajeswari, R. 1978. Eradication of Fusarium oxysporum f. sp. ciceri transmitted in chickpea seed. Phytopathol., 68: 13641368.

Haware, M.P. and Nene, Y.L. 1980. Influence of wilt at different stages on the yield 
loss in chickpea. Trop. Grain Legume Bull., 19: 38-40.

Kaur, N. P. and Mukhopadhyay, A.N. 1992. Integrated control of chickpea wilt complex by Trichoderma and chemical methods in India. Trop. Pest Management, 38, 372- 375.

Khan, M. R. and Gupta, J. 1998. Antagonistic efficacy Trichoderma species against Macrophomina phaseolina on eggplant. J. Plant Dis. Protection, 105: 387-393.

Khan, M.R., Khan, S.M. and Mohiddin, F.A. 2004. Biological control of Fusarium wilt of chickpea through seed treatment with the commercial formulation of Trichoderma harzianum and Pseudomonas fluorescens. Phytopathologia Mediterranea, 43: 2025 .

Kumar, M., Jain, A.K., Kumar, P., Chaudhary, S. and Kumar, S. 2008. Bioefficacy of Trichoderma spp. against management of chickpea damping-off caused by Rhizoctonia solani Kuhn. Plant Archi., 8: 399-400

Nikam, P.S., Jagtap, G.P and Sontakke, P.L. 2007. Management of chickpea wilt caused by Fusarium oxysporium f. sp. Ciceris. African Journal of Agricultural Research. 2 (12): 692-697.

Prasad, R. D., Rangeshwaran, R., Anuroop, C. P. and Rashmi, H.J. 2002. Biological control of wilt and root rot of chickpea under field conditions. Annals of Plant Protection Sci., 10: 72-75.

R.N. Pandey, N.M. Gohel and Pratik Jaisani (2017). Management of Wilt and Root Rot of Chickpea caused by Fusarium oxysporum f. sp. ciceri and Macrophomina phaseolina through Seed Biopriming and Soil Application of Bio-AgentsInt. J. Curr. Microbiol. App. Sci 6(5): 2516-2522

Sharma, S.N., Sunita Chandel and Manica Tomar. 2005. Integrated management of Fusarium yellows of gladiolus caused by Fusarium oxysporum f. sp. gladioli Snyder \& Hans. under polyhouse conditions. Integrated plant disease management. Challenging problems in horticultural and forest pathology, Solan, India. 2003. pp. 221-229.

\section{How to cite this article:}

Chudasama, M.K. and Pithia, M.S. 2018. Integrated Management of Wilt Disease in Chickpea. Int.J.Curr.Microbiol.App.Sci. 7(02): 951-956. doi: https://doi.org/10.20546/ijcmas.2018.702.118 